\title{
Penerapan Politik Kriminal dalam Penanggulangan Tindak Pidana Terorisme
}

\author{
Ryan Aditama ${ }^{1}$ \\ Fakultas Hukum Universitas Batanghari \\ Correspondence email: ryan.aditama31@gmail.com
}

\begin{abstract}
Abstrak. Penerapan politik kriminal dalam penanggulangan tindak pidana terorisme merupakan tindakan pencegahan yang dapat dilakukan untuk menekan angka kejahatan tindak pidana terorisme. Tindak pidana terorisme merupakan kejahatan terorganisir, memiliki jaringan nasional maupun internasional yang sangat meresahkan dan menjadi perhatian dunia. Tindak pidana terorisme setiap saat akan terjadi dengan sasaran yang tidak dapat diprediksi, tindakannya menimbulkan ketakutan masyarakat secara luas, menimbulkan korban jiwa dan kerugian harta benda yang tidak sedikit, juga menimbulkan dampak yang sangat luas terhadap kehidupan berbangsa dan bernegara. Mengingat tindak pidana terorisme itu merupakan tindak pidana yang luar biasa maka penanggulangannya juga dengan menggunakan cara yang tidak biasa seperti kejahatan biasa pada umumnya. Penerepan politik kriminal ini merupakan upaya preventif yang dapat dilakukan pihak pemerintah dalam mencegah munculnya tindak pidana terorisme.
\end{abstract}

Kata Kunci: Politik kriminal, Tindak Pidana Terorisme

Abstract. The application of criminal politics in the handling of criminal acts of terrorism is a preventive measure that can be taken to reduce the crime rate of terrorism. Terrorism is an organized crime, has a national and international network that is very troubling and concerns the world. Criminal acts of terrorism will occur at any time with unpredictable targets, their actions cause widespread public fear, cause casualties and property losses that are not small, also cause a very broad impact on the life of nation and state. Considering that the crime of terrorism is an extraordinary criminal act, it will also be overcome by using unusual methods such as ordinary crime in general. The preservation of criminal politics is a preventive effort that can be carried out by the government in preventing the emergence of criminal acts of terrorism.

Keywords: Criminal politics, Crime of Terrorism

\section{PENDAHULUAN}

Negara kita adalah negara berkembang yang sedang melaksanakan pembangunan di segala bidang, dengan tujuan pokok untuk memberikan kemakmuran dan kesejahteraan lahir dan batin bagi seluruh rakyat Indonesia. Hal ini dapat tercapai apabila masyarakat mempunyai kesadaran bernegara dan berusaha untuk mewujudkan masyarakat yang adil, makmur dan sejahtera.

Namun untuk beberapa orang atau sekelompok orang, merasa negara Indonesia tidak sesuai dengan yang mereka inginkan, baik dari segi pemerintahannya maupun hal-hal yang ada didalamnya. Maka dari itu sekelompok orang tersebut membuat suatu tindakan yang bertujuan untuk membuat takut dan resah masyarakat dan pemerintah, dengan melakukan tindakan terorisme.

Tindak pidana terorisme merupakan kejahatan terorganisir, memiliki jaringan nasional maupun internasional yang sangat meresahkan dan menjadi perhatian dunia. Tindak pidana terorisme setiap saat akan terjadi dengan sasaran yang tidak dapat diprediksi, tindakannya menimbulkan ketakutan masyarakat secara luas, menimbulkan korban jiwa dan kerugian harta benda yang tidak sedikit, juga menimbulkan dampak yang sangat luas terhadap kehidupan berbangsa dan bernegara. Terjadinya tindak pidana terorisme tidak dapat dikatakan dapat muncul dengan sendirinya, melainkan adanya faktor-faktor lain yang dapat mendorong munculnya tindak pidana terorisme seperti perkembangan situasi dalam dunia global mempunnyai pengaruh yang sangat besar.

Terorisme adalah suatu kejahatan yang tidak dapat digolongkan sebagai kejahatan biasa. Secara akademis, terorisme dikategorikan sebagai "kejahatan luar biasa" atau "extraordinary crime" dan dikategorikan pula sebagai "kejahatan terhadap kemanusiaan" atau "crime against humanity" . ${ }^{2}$ Mengingat

${ }^{1}$ Dosen Fakultas Hukum Universitas Batanghari Jambi

${ }^{2}$ Keterangan Pemerintah tentang diterbitkannya Perpu Nomor 1 Tahun 2002 Tentang Pemberantasan Tindak Pidana Terorisme yang disampaikan oleh Menteri Kehakiman dan Hak Asasi Manusia, Departemen Kehakiman dan Hak Asasi Manusia, tahun 2002, hlm 8 . 
kategori yang demikian maka pemberantasannya tentulah tidak dapat menggunakan cara-cara yang biasa sebagaimana menangani tindak pidana biasa seperti pencurian, pembunuhan atau penganiayaan.

Negara Indonesia, sebenarnya sebelum terjadinya serangan teror bom di Amerika Serikat pada tanggal 11 September 2001, dan jauh sebelum terjadinya tragedi bom bali pada tanggal 12 Oktober 2002, sejak tahun 1999 telah mengalami dan mengatasi aksi-aksi teror di dalam negeri. Data yang ada pada POLRI menunjukkan bahwa pada periode tahun 1999 sampai dengan tahun 2002 bom yang meledak tercatat 185 buah, dengan korban meninggal dunia 62 orang dan luka berat 22 orang. ${ }^{3}$ Peristiwa ledakan bom Bali di kawasan wisata Legian, Kuta, Bali telah menambah lembaran hitam kejahatan terhadap kemanusiaan di Indonesia.

Pemerintah Republik Indonesia dengan mendasarkan pada ketentuan Pasal 22 ayat (1) UUD 1945, yaitu syarat "hal ikhwal kegentingan yang memaksa" bertekad segera bertindak untuk mengungkap peristiwa bom Bali dengan mengantisipasi segala kemungkinan yang akan terjadi kembali, peristiwaperistiwa yang menelan korban jiwa dan harta benda. Untuk itu pemerintah mengeluarkan kebijakan dengan menetapkan Peraturan Pemerintah Pengganti Undang-Undang (PERPU) Nomor 2 Tahun 2002 tentang pemberlakuan PERPU Nomor 1 tahun 2002 tentang Pemberantasan Tindak Pidana Terorisme pada peristiwa peledakan bom Bali.

Peraturan Pemerintah Pengganti Undang-Undang (PERPU) Nomor 1 Tahun 2002 yang kemudian disetujui menjadi Undang-Undang Pemberantasan Tindak Pidana Terorisme yaitu Undang-Undang Nomor 15 Tahun 2003 secara spesifik juga memuat perwujudan ketentuan-ketentuan yang dikeluarkan Perserikatan Bangsa-Bangsa (PBB) dalam Convention Against Terorism Bombing (1997) dan Convention on the Suppression of Financing Terorism (1997), antara lain memuat ketentuan-ketentuan tentang lingkup yuridiksi yang bersifat transnasional dan internasional serta ketentuan-ketentuan khusus terhadap tindak pidana terorisme internasional.

Penggunaan Peraturan Pemerintah Pengganti Undang-Undang Nomor 2 Tahun 2002 didasarkan pada pertimbangan bahwa terjadinya terorisme di berbagai tempat di Indonesia telah menimbulkan kerugian baik materil maupun immateril serta menimbulkan ketidakamanan bagi masyarakat oleh karena itu setelah menjadi Undang-Undang Nomor 15 Tahun 2003, Undang-Undang tersebut telah menjadi payung hukum dalam pemberantasan tindak pidana terorisme. Selain itu Undang-Undang Pemberantasan Terorisme ini juga diatur tentang ancaman sanksi pidana minimum khusus untuk memperkuat fungsi penjeraan terhadap pelaku tindak pidana terorisme.

Menurut Barda Nawawi Arief, kebijakan atau upaya penanggulangan kejahatan (politik kriminal) pada hakikatnya merupakan bagian integral dari upaya perlindungan masyarakat (social defence) dan upaya mencapai kesejahteraan masyarakat (social welfere). ${ }^{4}$ Oleh karena itu dapatlah dikatakan bahwa tujuan akhir dari politik kriminal adalah perlindungan masyarakat untuk mencapai kesejahteraan masyarakat. Kebijakan untuk menggali tindak pidana terorisme juga terlihat dalam Rancangan Kitab Undang-Undang Hukum Pidana (KUHP) Nasional yaitu dalam dalam Buku II Bab I Bagian Keempat tentang Tindak Pidana Terorisme khususnya Pasal 242 sampai dengan Pasal 251. ${ }^{5}$

Dari berbagai tahap kebijakan tersebut di atas penulis tertarik untuk mengkaji dan meneliti lebih mendalam bagaimana kebijakan pemerintah dalam menanggulangi tindak pidana terorisme yang merupakan salah satu tindak pidana terorganisir di Indonesia dengan hukum pidana. Di dalam penanggulangan tindak terorisme di Indonesia selama ini ada pihak-pihak yang telah merasa puas dan dapat menerima tetapi mengapa ada juga yang tidak merasa puas dengan cara atau hasil pelaksaan hukum pidana terhadap tindak pidana terorisme. Berdasarkan penjelasan di atas maka akan dilakukan penelitian yuridis normatif terhadap penerapan politik kriminal dalam penanggulangan tindak pidana terorisme.

\section{METODE PENELITIAN}

\footnotetext{
${ }^{3}$ Susilo Bambang Yudhoyono, Selamatkan Negeri Kita dari Terorisme, cetakan pertama Kementriaan Polkam, Oktober, 2002, hlm. 7.

${ }^{4}$ Barda Nawawi Arief, Bunga Rampai Kebijakan Hukum Pidana, PT. Citra Aditya Bakti, Bandung, 2002, hlm.2

${ }^{5}$ Rancangan Undang-undang Republik Indonesia Tentang Undang-Undang Hukum Pidana (KUHP) 2008, www.legalitas.org.
} 
Dalam penelitian ini penulis menggunakan tipe penelitian yuridis normatif yaitu penelitian yang difokuskan kepada norma-norma yang terdapat dalam suatu peraturan perundang-undangan, sedangkan pendekatan yang digunakan adalah pendekatan perundang-undangan dan pendekatan konsep dengan cara mengungkapan beberapa asas-asas hukum yang berkaitan dengan politik kriminal dalam penanggulangan tindak pidana terorisme, pembahasan dilakukan dengan cara deduktif untuk memperoleh kesimpulan yang bersifat kualitatif.

\section{HASIL DAN PEMBAHASAN}

\section{Kebijakan Legislatif Dalam Penanggulangan Tindak Pidana Terorisme}

Kebijakan penegakan hukum pidana merupakan serangkaian proses yang terdiri dari tiga tahapan kebijakan yaitu (1) tahap kebijakan legislatif/formulatif, (2) tahap kebijakan yudikatif/aplikatif dan (3) tahap kebijakan eksekutif/administratif. Ketiga tahap kebijakan hukum pidana tersebut di dalamnya terkandung tiga kekuasaan/ kewenangan yaitu kekuasaan legislatif/formulatif untuk menetapkan atau merumuskan hukum pidana oleh pembuat undang-undang, kekuasaan yudikatif/aplikatif adalah tahap penerapan hukum pidana oleh aparat penegak hukum atau pengadilan dan kekuasaan eksekutif/administratif adalah tahap pelaksanaan pidana oleh aparat pelaksana/ eksekusi pidana.

Tahap kebijakan legislatif yang dapat juga disebut tahap formulasi, merupakan salah satu mata rantai dari perencanaan penegakan hukum, khususnya adalah bagian dari proses konkretisasi pidana. Tahap kebijakan legislatif ini merupakan tahap awal dan sekaligus merupakan sumber landasan dari proses konkretisasi pidana berikutnya, yaitu tahap penerapan pidana dan tahap pelaksanaan pidana.

Sistem pemidanaan dalam tahap kebijakan legistalif/formulatif pada hakekatnya merupakan sistem kewenangan/kekuasaan untuk menjatuhkan pidana. Pengertian "pidana" dapat dilihat dalam arti sempit/formal maupun dalam arti luas/materiil.

Dalam arti sempit/formal penjatuhan pidana berarti kewenangan menjatuhkan /mengenakan sanksi pidana menurut undang-undang oleh pejabat berwenang (hakim). Sedangkan dalam arti luas/materiil penjatuhan pidana merupakan suatu mata rantai proses tindakan hukum dari pejabat yang berwenang mulai dari proses penyidikan, penuntutan sampai pada putusan pidana dijatuhkan oleh pengadilan dan dilaksanakan oleh aparat pelaksana pidana.

Berdasarkan kenyataan-kenyataan yang terjadi di dalam masyarakat, Pemerintah Republik Indonesia sebagai pihak yang bertanggung jawab atas keselamatan bangsa dan negara, memandang perlu untuk sesegera mungkin memiliki landasan hukum yang kuat dan komprehensif untuk memberantas tindak pidana terorisme. Pemerintah menyadari bahwa norma-norma hukum yang ada sekarang seperti yang termaktub dalam Undang-Undang Nomor 12 Drt Tahun 1951 tentang Senjata Api yang hanya memuat tindak pidana biasa (ordinary crime) tidaklah memadai untuk memberantas tindak pidana terorisme yang merupakan kejahatan luar biasa (extra ordinary crime).

Ketentuan-ketentuan dalam Undang-Undang Nomor 8 Tahun 1981 tentang Hukum Acara Pidana juga dirasakan kurang memadai. Proses penyelidikan, penyidikan dan penuntutan terhadap tindak pidana terorisme memerlukan ketentuan-ketentuan khusus yang diatur tersendiri, disamping ketentuan-ketentuan umum yang berlaku di dalam Kitab Undang-Undang Hukum Acara Pidana.

Untuk mengantisipasi terjadinya segala kemungkinan dengan kegiatan terorisme, maka Pemerintah Indonesia berpendapat adanya syarat "hal ihwal kegentingan yang memaksa" sebagaimana diatur Pasal 22 Ayat (1) Undang-Undang Dasar 1945 telah terpenuhi. Pemerintah bertekad untuk segera bertindak mengungkap peristiwa peledakan bom di Bali dan mengantisipasi segala kemungkinan yang akan terjadi. Untuk itu Pemerintah mengeluarkan kebijakan dengan menetapkan Peraturan Pemerintah Pengganti Undang-Undang (PERPU) Nomor 1 Tahun 2002 tentang Pemberantasan Tindak Pidana Terorisme dan Nomor 2 Tahun 2002 tentang Pemberlakuan Perpu Nomor 1 Tahun 2002 tentang Pemberantasan Tindak Pidana Terorisme pada Peristiwa Peledakan Bom di Bali tanggal 12 Oktober 2002.56) Lahirnya 2 (dua) ketentuan tersebut dengan cepat disetujui oleh Dewan Perwakilan Rakyat (DPR) dan juga melahirkankontroversi, seperti misalnya :

1. Adanya kecenderungan politik kontrol melalui organisasi intelijen dan militer.

2. Adanya kekhawatiran pemberangusan kebebasan masyarakat sipil yang akan menganulir proses demokratisasi. 


\section{Efektifitas Politik Kriminal Dalam Penanggulangan Tindak Pidana Terorisme}

Tujuan utama yang ingin dicapai pidana dan hukum pidana sebagai salah satu sarana dari politik kriminal adalah "perlindungan masyarakat". Tujuan perlindugan masyarakat inilah yang menurut Cherif. M Bassiouni merupakan batu landasan (a cornerstone) dari hukum pidana. Tujuan tersebut merupakan induk dari keseluruhan pendapat atau teori-teori mengenai tujuan pidana. Dengan perkataan lain, semua pendapat dan teori yang berhubungan dengan tujuan pidana dan pemidanaan sebenarnya hanya merupakan perincian atau pengidentifikasian dari tujuan umum itu.

Tujuan yang ingin dicapai dengan pidana dan hukum pidana selama ini belum pernah dirumuskan secara formal dalam undang-undang. KUHP yang merupakan peraturan yang berisi ketentuan-ketentuan umum hukum pidana materiil tidak mengatur masalah tujuan pemidanaan ini. Namun dalam rancangan KUHP Nasional tahun 2000 dirumuskan tujuan pemidanaan yang hendak dicapai.

Barda Nawawi Arief yang mengambil pendapat Gene Kassebaum menyatakan bahwa penanggulangan kejahatan dengan menggunakan sanksi pidana merupakan cara yang paling tua, setua peradaban manusia itu sendiri. Adapula yang menyebutnya sebagai "older philosophy of crime control". Herbert L. Packer juga mengemukakan bahwa pengendalian perbuatan anti sosial dengan menggunakan pidana pada seseorang yang bersalah merupakan suatu problem sosial yang mempunyai dimensi hukum yang penting. ${ }^{6}$

Lebih lanjut dikemukakan oleh Barda Nawawi Arief :

"salah satu bentuk dari perencanaan perlindungan sosial adalah usaha-usaha yang rasional untuk menanggulangi kejahatan yang biasa disebut dengan "politik kriminal". Tujuan akhir dari kebijakan kriminal adalah "perlindungan masyarakat" untuk mencapai tujuan utama yang sering disebut dengan istilah, misalnya "kebahagiaan warga masyarakat" (happines of the citizens), "kehidupan kultural yang sehat dan menyegarkan" (a holesome and cultural living), "kesejahteraan masyarakat" (social welfare) atau untuk mencapai "keseimbangan" (equalitiy). Dengan demikian politik kriminal yang merupakan bagian dari perencanaan perlindungan masyarakat merupakan bagian pula dari keseluruhan kebijakan sosial".

Sehubungan dengan konsep pemikiran yang demikian itu, maka Sudarto mengemukakan bahwa apabila hukum pidana hendak dilibatkan dalam usaha-usaha mengatasi segi negatif dari perkembangan masyarakat, maka hendaknya dilihat dalam hubungan keseluruhan politik kriminal atau social defence planning. Dikemukan pula selanjutnya, bahwa social defence planning ini pun harus merupakan bagian integral dari rencana pembangunan nasional.

Politik kriminal menurut Sudarto mempunyai tiga arti, yaitu :

a. "dalam arti sempit", ialah keseluruhan asas dan metode yang menjadi dasar dari reaksi terhadap pelanggaran hukum yang berupa pidana;

b. dalam arti luas, ialah keseluruhan fungsi dari aparatur penegak hukum, termasuk di dalamnya cara kerja pengadilan dan polisi;

c. dalam arti paling luas (yang beliau ambir dari Jorgen Jepsen) ialah keseluruhan kebijakan, yang dilakukan melalui perundang-undangan dan badan-badan resmi, yang bertujuan untuk menegakkan norma-norma sentral dari masyarakat".

Sedangkan menurut G.P. Hoefnagels Upaya penanggulangan kejahatan (Politik Kriminal) dapat ditempuh dengan :

a. "penerapan hukum pidana (criminal law aplication);

b. pencegahan tanpa pidana (prevention without punishment);

c. mempengaruhi pandangan masyarakat mengenai kejahatan dan pemidanaan lewat media massa (influencing views of society on crime and punishment / mass media)".

Dengan demikian upaya penanggulangan kejahatan (politik kriminal) secara garis besar dapat dibagi menjadi dua, yaitu lewat jalur "penal" (hukum pidana) dan lewat jalur "non-penal" (bukan/di luar hukum pidana). Dalam pembagian di atas, upaya-upaya yang disebut dalam butir (a) merupakan upaya

${ }^{6}$ Barda Nawawi Arief, Masalah Penegakan Hukum dan Penanggulangan Kejahatan, PT. Citra Aditya Bakti, Bandung, 2001, hal 155-156. 
"penal, sedangkan upaya-upaya yang disebut dalam butir (b) dan (c) dapat dimasukkan dalam kelompok upaya "non penal".

Kebijakan atau politik hukum pidana merupakan bagian dari politik penanggulangan kejahatan (politik kriminal). Dengan perkataan lain politik hukum pidana identik dengan pengertian kebijakan penanggulangan kejahatan dengan hukum pidana. Kebijakan atau politik hukum pidana pada hakekatnya juga merupakan bagian dari usaha penegakan hukum (khususnya penegakan hukum pidana), sehingga dapat dikatakan bahwa politik atau kebijakan hukum pidana merupakan bagian pula dari kebijakan penegakan hukum (law enforcement policy).

Suatu tindakan dinyatakan telah efektif, jika sudah tercapai tujuannya. Seperti haknya dengan tindakan yang dilakukan pemerintah dengan berbagai kebijakan / politik kriminalnya, bisa kita cermati, bahwa tindakan-tindakan yang dilakukan oleh pemerintah baik penal maupun non penal sudah cukup efektif dalam penanggulangan tindak pidana terorisme ini, dengan telah ditangkap dan dihukumnya para pelaku terorisme tersebut, dengan hukuman yang sesuai. Namun hal tersebut bukan berarti pemerintah telah benar-benar sukses tanpa kendala dalam melakukan tindakan-tindakan baik pencegahan maupun penanggulangannya. Dan hambatan-hambatan tersebut cukup membuat efektifitas politik kriminal dalam penanggulangan tindak pidana terorisme menjadi sedikit terhambat. Hal ini terlihat dari proses penyelidikan dan penyidikan yang memakan waktu yang lama untuk mengumpulkan bukti-bukti serta menemukan para pelaku yang notabene berkelompok dengan jaringan yang sangat luas. Para pelaku yang cukup pintar juga menghambat kinerja para penegak hukum, dalam hal ini tindakan non penal sangatlah diperlukan untuk meningkatkan efektifitas dari tindakan-tindakan pencegahan dan penanggulangan kasus teroris tersebut.

\section{Langkah-langkah Antisipasi dan Penanggulangannya Preventif}

1. Meratifikasi Resolusi PBB No. 1373 dan No. 1377 tentang ajakan aksi bersama untuk memerangi terorisme dan Resolusi No.1267 tentang pencantuman kelompok tertentu sebagai organisasi teroris internasional serta resolusi No.1390 tentang pembekuan aset teroris dan pencegahan aksi terorisme lintas batas negara.

2. Memberikan pemahaman dan pengetahuan terhadap undang-undang yang telah disahkan yaitu UndangUndang Anti Terorisme No. 15 tahun 2003 dengan harapan seluruh anggota Polri memahami dan mampu mengaplikasikan dalam mengungkap berbagai macam tindak pidana terorisme

3. Berupaya memfasilitasi terhadap berbagai keperluan peralatan deteksi untuk kepentingan pelaksanaan tugas anggota satuan pengamanan

4. Meningkatkan peran serta masyarakat melalui tokoh-tokoh masyarakat, tokoh agama untuk:

a. Mengeliminir faktor niat dengan memberikan pemahaman tentang jihad yang sesuai dengan ajaran agama yang sebenarnya.

b. Menciptakan masyarakat yang memiliki kesadaran untuk berperan serta dalam menciptakan situasi keamanan yang kondusif yang kita harapkan bersama.

5. Kerjasama regional dan internasional :

a. Dengan semangat dan keseriusan dalam memerangi kejahatan antar negara, negara-negara yang tergabung dalam ASEAN telah menyepakati melalui deklarasi Asean tanggal 20 Desember 1997 di Manila dimana terorisme telah ditetapkan sebagai salah satu Trans National Crime.

b. Pada pertemuan tingkat mentri luar negeri antar negara ASEAN (AMMTC/Asean Ministery on Trans National Crime) telah menetapkan kesepakatan kerja sama Asean dalam menanggulangi trans nastional crime yang mana Indonesia khususnya Polri di tetapkan sebagai Focal Point dalam penanggulangan terorisme

c. Turut serta secara aktif dalam berbagai forum regional dan internasional dalam rangka membahas kejahatan lintas negara (trans national crime) termasuk didalamnya kasus terorisme.

d. Melakukan pertukaran informasi terorisme antar negara Asean dan negara lain sebagaimana yang sekarang telah dilaksanakan kerjasama dengan Kepolisian Australia dalam pembentukan TNCC (trans national crime center) yang ditempatkan di Mabes Polri, disamping itu juga mendirikan JCLEC (Jakarta Center for Law Enforcement Cooperation) yang berada di Akpol Semarang.

e. Melaksanakan kerjasama dengan luar negeri dalam rangka pengungkapan maupun pengejaran 
6. Pembentukan Satuan Anti Teror :

a. Pembentukan unit khusus anti teror di Mabes Polri yaitu Detasemen Khusus 88/ Anti Terror dan

b. Membentuk satuan tugas (satgas Bom) serta pembentukan satuan-satuan anti teror di Polda-Polda terutama pada Polda yang rawan terjadinya tindak pidana terorisme.

c. Pembentukan lembaga pendidikan khusus anti teror yang diberi nama PLATINA (Pusat Latihan Anti Teror Indonesia) sebagaimana yang telah didirikan pada tahun 2004 yang berada di Akpol Semarang

7. Peningkatan Kwalitas Satuan Anti Teror :

a. Mengintensifkan kegiatan deteksi dini dalam upaya pengungkapan kasus terorisme.

b. Mengikut sertakan program pendidikan anti teror yang telah di programkan dalam pendidikan di PLATINA (Pusat Latihan Anti Terorisme Indonesia).

c. Memanfaatkan semaksimal mungkin bantuan pelatihan anti teror dari Australia (TNCC,JCLEC), Amerika dalam progran ATA (Anti Terorisme Assistance)., Jerman, Jepang dan sebagainya.

d. Mengembangkan peralatan tehnologi anti teror dengan mengadakan alat-alat komunikasi, identifikan dan sarana prasarana mobilitas.

8. Meningkatkan Peran Intelijen dalam:

a. Melaksanakan deteksi dini terhadap jaringan para pelaku yang belum tertangkap mengenai kegiatankegiatan yang masih dilakukan oleh para pelaku dan kaitannya dengan jaringan lainnya baik yang masih berada di Indonesia maupun jaringannya yang berada di luar negeri.

b. Intelijen harus dapat memberikan masukan terhadap pimpinan tentang hasil deteksi dini tersebut yang merupakan early warning dan early detekting sehingga diharapkan pimpinan dapat mengambil langkah-langkah menentukan kebijaksanaan

c. Membentuk jaringan intelijen yag dapat memberikan gambaran tentang keberadaan maupun kondisi serta situasi para pelaku terorisme,

d. Meningkatkan peran serta masyarakat melalui tokoh-tokoh masyarakat, tokoh agama untuk melakukan pembinaan kepada masyarakat agar masyarakat mempunyai daya tangkal terhadap para pelaku tindak pidana terorisme dengan melaporkan setiap ada orang atau kelompok orang yang patut di curigai akan/telah melakukan tindak pidana terorisme.

e. Meningkatkan kewaspadaan para anggota satuan pengamanan dengan cara melakukan pendataan pekerja, pengunjung dan mewaspadai orang-orang yang dicurigai (daftar pencarian orang).

f. Menggalakkan media masa untuk menciptakan opini yang mampu meningkatkan kesadaran dan kewaspadaan masyarakat terhadap ancaman terorisme.

\section{Represif}

a. Melakukan pelacakan terhadap aset milik pelaku teror dan melakukan pembekuan rekening pelaku teroris dengan bekerja sama dengan Bank Indonesia.

b. Melakukan penyelidikan dengan cara konvensional maupun dengan memanfaatkan tehnologi canggih yang hasilnya dianalisa untuk mencari keberadaan para pelaku teror, untuk menemukan barang bukti maupun untuk mengungkap jaringannya baik jaringan nasional maupun internasional.

c. Melakukan introgasi maupun pemeriksaan terhadap para tersangka dengan menggunakan tehnik-tehnik tertentu yang dapat mengunkap mulai dari proses perencanaan sampai dengan terlaksananya tindak pidana terorisme dengan memperhatikan peraturan-peraturan hukum yang berkaku dan menjunjung tinggi hak azasi manusia.

d. Melakukan penggeledahan terhadap badan tersangka maupun tempat-tempat lain untuk menemukan barang bukti baik dengan cara konvensional maupun dengan bantuan peralatan tehnologi canggih guna mendukung pembuktian dalam proses peradilan.

e. Melakukan penyitaan barang bukti baik yang berkaitan langsung maupun tidak langsung dengan tindak pidana terorisme yang telah/belum terjadi.

f. Melakukan penahanan terhadap para tersangka tindak pidana yang telah memenuhi unsur pidana sebagaimana dalam undang-undang nomor 15 tahun 2003 tentang pemberantasan tindak pidana terorisme.

g. Melakukan pemberkasan terhadap perkara yang telah ditangani yang selanjutnya diserahkan ke penuntut umum dalam rangka proses persidangan. 
h. Melakukan tindakan-tindakan lain berdasarkan hukum yang berlaku dalam rangka penanggulangan dan pemberantasan tindak pidana terorisme di Indonesia.

\section{Rehabltasi}

Bekerjasama dengan instansi terkait dalam rangka melakukan rehabilitasi terhadap para pelaku dengan melakukan pembinaan maupun penempatan secara khusus dalam pelaksanaan penahanan yang dilakukan oleh Polri maupun pelaksanaan hukuman di lembaga pemasyarakatan.

\section{Hambatan-hambatan dalam melakukan lawenforcement (menegakkan hukum)}

Tindak Pidana Terorisme yang selama ini terjadi telah mengganggu keamanan dan ketertiban masyarakat serta merupakan ancaman serius terhadap kedaulatan negara, sehingga pencegahan dan pemberantasan tindak pidana terorisme perlu dilakukan secara berencana dan berkesinambungan guna memelihara kehidupan yang aman, damai dan sejahtera.

Masalah penahanan terhadap tersangka terorisme juga tidak ada perubahan padahal masalah penahanan merupakan paling menentukan proses hukum tersangka terorisme. Masyarakat selama ini hanya melihat hasilnya bahwa pihak Kepolisian telah berhasil menangkap dan mengungkap jaringan terorisme dan membawanya kepengadilan, tetapi tidak melihat kesulitan-kesulitan yang dihadapi petugas-petugas di lapangan karena terbatasnya waktu penahanan yang ditentukan undang-undang.

Pembentukan Undang-Undang Nomor 15 Tahun 2003 tentang Pemberantasan Tindak Pidana Terorisme di Indonesia, merupakan kebijakan dan langkah antisipatif yang bersifat proaktif yang di landaskan kepada kehati-hatian dan bersifat jangka panjang, karena masyarakat Indonesia adalah masyarakat multi etnik dan mendiami ratusan ribu pulau yang tersebar di seluruh wilayah nusantara, letaknya ada yang berbatasan dengan negara lain dan oleh karenanya seluruh komponen bangsa Indonesia berkewajiban memelihara dan meningkatkan kewaspadaan akan adanya segala bentuk kegiatan tindak pidana terorisme, disamping itu konflik yang sering terjadi di berbagai daerah di Indonesia berakibat sangat merugikan kehidupan bangsa Indonesia yang menyebabkan kemunduran peradaban yang pada akhirnya Indonesia akan dapat menjadi tempat subur perkembangnya terorisme baik yang dilakukan orang Indonesia sendiri maupun orang asing.

Organisasi teroris adalah organisasi rahasia yang bersifat tertutup dan setiap anggotanya harus disiplin dan menjaga kerjasa yang bersifat tertutup pula. Berdasarkan pengalaman para pemburu terorir, menangkap jaringan teroris dengan cara biasa yang mengacu pada Kitab Undang-Undang Hukum Acara Pidana akan mempersulit proses penangkapan selanjutnya. ${ }^{7}$ Hal ini dapat dibuktikan dengan jarak waktu penangkapan kelompok satu dengan kelompok lainnya memerlukan waktu 2 (dua) bulan atau lebih, dan waktu proses penangkapan selanjutnya memerlukan waktu yang lebih lama lagi karena jaringan tersangka teroris juga mempelajari pola penangkapan rekan-rekan mereka.

Adapun hambatan-hambatan dalam melakukan law enforcement (menegakkan hukum) terhadap kejahatan terorganisir ini, yang paling prinsip adalah sebagai berikut: ${ }^{8}$

1. Organisasi kejahatan tersebut cukup canggih sehingga tidak mudah terdeteksi.

2. Organisasi kejahatan tersebut cepat menyesuaikan diri mengikuti perkembangan teknologi penyidikan penegak hukum.

3. Organisasi kejahatan memegang penegak hukum dan pejabat pemerintah dengan cara menyuap.

4. Organisasi kejahatan membunuh penegak hukum dan pejabat pemerintah yang tidak bisa disuap.

5. Penegak hukum dan pejabat pemerintah takut dengan ancaman pembunuhan oleh organisasi kejahatan.

6. Para anggota organisai kejahatan menjalankan kewajibannya (perintah atasan) dengan disiplin yang tinggi karena taruhannya adalah nyawa.

\section{SIMPULAN}

Menurut Barda Nawawi Arief, kebijakan penanggulangan kejahatan yang dituangkan dalam peraturan perundang-undangan secara garis besar meliputi :

${ }^{7}$ Bekto Suprapto, Pengalaman Investigasi Kasus Terorisme di Indonesia dan Permasalahannya, Seminar Penanganan Terorisme Reg Tindak Pidana Khusus, Jakarta, 28 Juni 2001.

${ }^{8} \mathrm{http}: / /$ djicom.wordpress.com/2010/01/10/kejahatan-terorganisir/ 
a. Perencanaan atau kebijakan tentang perbuatan-perbuatan terlarang apa yang akan ditanggulangi karena dipandang membahayakan atau merugikan.

b. Perencanaan atau kebijakan tentang sanksi apa yang dapat dikenakan terhadap pelaku perbuatan terlarang itu (baik berupa pidana atau tindakan) dan sistem penerapan.

Suatu tindakan dinyatakan telah efektif, jika sudah tercapai tujuannya. Seperti haknya dengan tindakan yang dilakukan pemerintah dengan berbagai kebijakan / politik kriminalnya, bisa kita cermati, bahwa tindakan-tindakan yang dilakukan oleh pemerintah baik penal maupun non penal sudah cukup efektif dalam penanggulangan tindak pidana terorisme ini, dengan telah ditangkap dan dihukumnya para pelaku terorisme tersebut, dengan hukuman yang sesuai. Namun hal tersebut bukan berarti pemerintah telah benar-benar sukses tanpa kendala dalam melakukan tindakan-tindakan baik pencegahan maupun penanggulangannya. Dan hambatan-hambatan tersebut cukup membuat efektifitas politik kriminal dalam penanggulangan tindak pidana terorisme menjadi sedikit terhambat. Hal ini terlihat dari proses penyelidikan dan penyidikan yang memakan waktu yang lama untuk mengumpulkan bukti-bukti serta menemukan para pelaku yang notabene berkelompok dengan jaringan yang sangat luas. Para pelaku yang cukup pintar juga menghambat kinerja para penegak hukum, dalam hal ini tindakan non penal sangatlah diperlukan untuk meningkatkan efektifitas dari tindakan-tindakan pencegahan dan penanggulangan kasus teroris tersebut.

\section{DAFTAR PUSTAKA}

\section{Buku}

Arief, Barda Nawawi, Bunga Rampai Kebijakan Hukum Pidana, PT. Citra Aditya Bakti, Bandung, 2015.

------, Masalah Penegakan Hukum dan Penanggulangan Kejahatan, PT. Citra Aditya Bakti, Bandung, 2011.

Kamus Besar Bahasa Indonesia, Badan Bahasa Kementerian Pendidikan dan Kebudayaan RI, Jakarta, 2013.

Soesilo, R. Kitab Undang-Undang Hukum Pidana (KUHP) Serta Komentar-Komentar Lengkap Pasal Demi Pasal, Politeia, Bogor, 1986.

Suprapto, Bekto, Pengalaman Investigasi Kasus Terorisme di Indonesia dan Permasalahannya, Seminar Penanganan Terorisme Reg Tindak Pidana Khusus, Jakarta, 28 Juni 2001.

Yudhoyono, Susilo Bambang, Selamatkan Negeri Kita dari Terorisme, cetakan pertama Kementriaan Polkam, Oktober, 2002.

\section{Perundang-Undangan}

Peraturan Pemerintah Pengganti Undang-Undang (PERPU) Nomor 2 Tahun 2002 tentang pemberlakuan PERPU Nomor 1 tahun 2002 tentang Pemberantasan Tindak Pidana Terorisme pada peristiwa peledakan bom Bali.

\section{Internet}

Rancangan Undang-undang Republik Indonesia Tentang Undang-Undang Hukum Pidana (KUHP) 2008, www.legalitas.org.

http://djicom.wordpress.com/2010/01/10/kejahatan-terorganisir/ 